\title{
Research on the Practical Operation Specification of Accounting Treatment of Pilot Enterprises Business Tax Changing
} to VAT

\author{
Liya Ma, Xingrui Zhang, Shufeng Wang* \\ Accounting College, Heilongjiang Bayi Agricultural Reclamation University, Daqing, China \\ Email: ${ }^{*}$ wsf630817@163.com, 51973759@qq.com
}

Received 20 April 2015; accepted 20 May 2015; published 22 May 2015

Copyright (C) 2015 by authors and Scientific Research Publishing Inc.

This work is licensed under the Creative Commons Attribution International License (CC BY). http://creativecommons.org/licenses/by/4.0/

(c) (i) Open Access

\begin{abstract}
August 1st, 2013, "Business tax change to VAT" implemented across the China. Based on this, the pilot enterprises and non-pilot enterprises do not exist within the same industry, while the difference of the tax levied of the small scale taxpayer also has been cancelled. This makes the accounting treatment provisions not fully meet to need to the new policy environment and situation of "BT change to VAT", while accounting and bookkeeping processing of the VAT have become a difficulty for pilot enterprises. Using literature retrieval, analogy analysis, judgment and reasoning method and the method of induction and deduction method, aiming at related to the latest change of policy released by the country and accounting treatment provisions to the "BT change to VAT" pilot enterprise released by the ministry of finance, therefore, this paper analyses the main business accounting of the "Camp changed to increase" pilot enterprises, and researches the standard operation mode of business accounting and the accounting treatment related to the "BT changed to VAT".
\end{abstract}

\section{Keywords}

Business Tax VAT, Accounting Treatment Practice, The Amount of Input Tax

\section{Introduction}

Since August 1st, 2013, China has implemented the policy of "Business tax change to vat" to the eight modern *Corresponding author.

How to cite this paper: Ma, L.Y., Zhang, X.R. and Wang, S.F. (2015) Research on the Practical Operation Specification of Accounting Treatment of Pilot Enterprises Business Tax Changing to VAT. Open Journal of Social Sciences, 3, 95-102. 
service industry, such as transportation (including railway transport and logistics auxiliary industry, research and development and technical services, cultural and creative services, information technology services, tangible personal property leasing, verification consulting services, and postal services and telecommunications in the national scope. Research shows that China "Business tax change to vat" policy, not only to optimize the structure of the national tax system, so that double-counting of sales tax levied phased out of new high-end services to intervene, so as to promote the rapid development of modern service industry, but also the effective convergence of VAT easy to interrupt the chain link deduction, so VAT can be healthy and smooth flow in all industries, to achieve between full correspondence of the output tax and input tax to upstream and downstream industries each link, ensure that the formation of the situation for should be deducted can be deducted, ultimately reduce the tax burden on the majority of enterprises, promote industrial recycling economy and efficient operation and healthy development [1]. Previously there have been the end of the accounting treatment of VAT scholars remaining tax credit, has made the accounting treatment of transitional financial support funds, the VAT tax control system equipment and technical maintenance costs offset VAT accounting treatment, the difference between the VAT levied four aspects of the accounting treatment, on the "Business tax change to vat" accounting practices were involved in the operation had a brief analysis. However, the starting point is the application for the policy interpretation issued by the Ministry of Finance in 2012 were aimed at guiding the "Business tax change to vat” the pilot enterprises accounting can be applied correctly carried out existing operators change in accounting policy [2]. However, as the scope of "Business tax change to vat" expanding gradually and the related industries united implement a trial policy across the country, accounting regulations lag obviously, tax-related business accounting and accounting issues are highlighted, and tax risk gradually increased of pilot enterprises. To this end, the "Business tax change to vat" in accounting policy reforms against at the new policy adjustment imperative and urgent, and there is a need to strengthen the research on accounting norms in the academic level to give practical guidance.

\section{The Adjustments of Accounting Policy of "Business Tax Change to VAT" Enterprise}

To coincide with the pilot work of "Business tax change to vat", the ministry of finance issued "accounting treatment provisions relating to the 'Business tax change to vat' pilot enterprise” (Finance and Accounting [2012] No. 13) (Hereinafter referred to as "accounting rules”) to make provision to a tax on pilot taxpayers difference and the final VAT tax credits, transitional financial support fund, VAT tax-controlled system, special equipment and maintenance fees deducted from the value-added tax accounting. So far, this is the only accounting regulation related to pilot enterprise issued by the government, and all kinds of pilot enterprises should comply with when they implement the accounting treatment by the end of 2014. As the pilot scope expands gradually and constant change of "Business tax change to vat" particularity policy adapted to the new expansion of pilot enterprises, taxpayers should be combined with the actual execution to adjust the accounting regulations properly.

\subsection{Settings of Accounting Account and Books}

According to the provisions of the accounting process, average taxpayer should set four subsidiary subjects, such as "VAT payable" "not pay value-added tax" "to offset the input tax" "beginning to leave for the payment of tax" under the "taxes payable” account. In "VAT payable” subsidiary ledger, borrower should set up "the input tax”, "has to pay taxes”, “export credits consumption tax payable”, and "turn out not to pay VAT” column, the lender should set up "output tax", “export tax refund”, "input tax roll out”, "turn out much pay VAT” column.

In accordance with regulation that "Ministry of Finance State Administration of Taxation: Notice on included the Railway Transportation and Postal Service in the Business Tax Paid VAT in the Pilot” (Finance and Accounting [2012] No. 106), general VAT taxpayers should calculate payable tax amount of the current period after sales shall offset the input tax amount. If the payable tax amount is negative, the current input tax has not been able to offset can be carried forward to offset, to form the final VAT tax credits of pilot enterprises. At the same time, according to regulation that "State Administration of Taxation: Announcement of Relevant Matters of VAT General Taxpayer Qualification on 'Business tax change to vat' Pilot Reform” (State Administration of Taxation, 2013, No. 75), pilot taxpayers, both selling goods, providing processing repairs and replacement services, and taxable services, should calculate taxable goods and services sales and taxable services sales sepa- 
rately, and be suitable to the VAT general taxpayer qualification. This means that goods and taxable services at the beginning of tax credits, cannot deduct output tax of taxable services, and vice versa. In this way, according to the regulation that Finance and Accounting [2012] No. 13, input tax without deduction happened in pilot enterprises can be calculated through settings "leave for the payment of tax beginning" under the "taxes payable" account.

Small-scale taxpayers need to set the "VAT payable" detail course, don't need to set the "VAT payable" detail course in the column. Therefore, taxpayers only need to set "three column" tax subsidiary ledger to registrate accounting provisions during the tax and the actual payable value-added tax.

\subsection{Accounting Treatment of "Business Tax Change to VAT" Business of Pilot Taxpayer}

1) Accounting Treatment of Difference Tax of Average Taxpayer

According to the regulation that "State Administration of Taxation: Announcement of Relevant Matters of VAT General Taxpayer Qualification on 'Business tax change to vat' Pilot Reform" (State Administration of Taxation, 2013, No. 75), pilot taxpayers who have a sales of more than 5 million yuan shall apply for average taxpayer before the implementation of the policy "Business tax change to vat". At present, the pilot taxpayer implement multi-candidate duty before "Business tax change to vat", but taxable services offered by the average taxpayer enterprises after "Business tax change to vat" should be calculated one by one by pilot enterprises and be provised in the accounting book. According to the relevant provisions of "Business tax change to vat", deducting the price from sales of paid to other taxpayers is allowed, but should set column "Output tax deduction of 'Business tax change to vat"” under the subject "Payable taxes-Payable VAT" to record output tax deducting the sales by the enterprises because of rules. At the same time, enterprises should calculate accounting details according to the types of business, such as "Main business income" "Main business cost". Pilot taxpayers providing taxable services, when the sales amount is not enough to offset and deduct project amount, sales amounts are not be allowed to be deducted after the particular day (should apply for refund to the original competent tax bureau tax).

a) Enterprise to accept taxable services:

Debit: Advocate business wu cost, etc.

Should hand in taxes-Payable VAT (Camp to increase output tax deduction).

Credit: Bank deposit or accounts payable.

b) The business to one-time accounting treatment in the final, daily business to pay the full amount credited to cost, the final summary out of the actual pay value-added tax and to Separated from the cost:

Debit: Should hand in taxes—-payable VAT (camp to increase output tax deduction).

Credit: Advocate business wu cost, etc.

2) Accounting treatment for small-scale taxpayers

At present, in addition to the railway transport enterprise shall be according to the "interim measures for the railway transport enterprise value-added tax levy management" (The state administration of taxation announced in 2014, No. 6) should unity identified as the general taxpayer Outside, pilot enterprises with annual sales turnover (Excluding tax) of less than 5 million yuan, shall be deemed to be small-scale taxpayers. Small scale taxpayer should the implementation of a monthly or quarterly tax declaration method. the daily sales of goods, Provide services and section taxable services, shall be in accordance with the provisions of the accounting standards of income confirmation standard and combined with the tax obligation stipulated time validation shall be taxable income, accounting may be calculated one by one tax, can also be on the daily income of business occurs according to the Price of including tax when sales occur for the main business income accounting and recorded. to pay taxes the end of the period, accounting in accordance with the settlement shall be taxable income according to the 3\% rate of levy accounting for current period sales and the amount of tax payable, into the "tax payableVAT payable" subject, and decreasing the main business income; the receiving taxable services, shall be deducted from any input tax amount. Accounting in enterprise daily occurrence of taxable services, the ad valorem tax total amount reflected the main business income and other income, the final summary accounting after VAT payable, debit offset related income, credit "should hand in taxes—VAT payable".

In addition, the accounting policy on "to replace business tax with value-added tax (VAT)" enterprise purchase tax control invoice machine equipment and its maintenance fees accounting treatment provisions, Is mutual connection with the current value-added tax accounting policy, the enterprised occurrence of this kind of economic business should carry out accounting treatment should abide by this policy. 
3) The VAT Remaining tax credit accounting treatment in the end of the period

Remaining tax credit is the special business of "Camp to increase" pilot enterprises at alternating phases of old and new, accordance with the relevant policies and regulations of "Camp to increase", The provide of taxable services original VAT general taxpayer, as of the beginning of the month to start a pilot VAT stay tax credit, can not be deducted from the output VAT taxable service, they should set up a "VAT remaining tax credit" detailed accounting subjects under "taxes payable" account. The end of the period, "Taxes payable-VAT remaining tax credit" account balance, to be presented according to their liquidity on the balance sheet in "Other current assets" [3].

a) The beginning of the pilot month, companies should not be deducted from the output VAT of taxable service in the The VAT Remaining tax credit of VAT (value-added tax and a breakdown of the existence of goods and taxable services remaining tax credit) to make:

Debit: Taxes payable-VAT remaining tax credit.

Credit: Taxes payable—VAT (Iinput tax turns out).

b) After the period has been calculated comparison, the time deducted from taxable goods and services output VAT allowed:

Debit: Taxes payable—VAT (VAT).

Credit: Taxes payable-VAT remaining tax credit.

It should be emphasized, since the VAT reverted to the State Revenue Tax Collection and management in during the pilot, But for the time being is not yet by "tax sharing" between the central and local governments were divided in proportionally distribution (75\% of the central and local 25\%) into, the income distribution is still the original business tax system under the provisions of full into the local financial treasury. Therefore, the Business tax change to vat the relevant policies and regulations, accounting book business has not left the pilot day deductible input tax, shall be deducted from the output VAT taxable services generated, so as not to affect the financial distribution relationships.

\section{Accounting and Accounting Standards of Vat Pilot Enterprises}

\subsection{VAT of Full Tax Pilot Enterprises on Accounting Standards}

Full tax "refers to pilot enterprises should be according to tax law and pay tax which based on total revenue and non-specializing business cost. To another way, any spending shall not be deducted from revenue is so called turnover. This type of pilot enterprises to could still get all sales output tax, while tax payable should minus input tax. If parent organization collect taxes, branch or company should pay VAT by month. When parent company aggregate taxes, they always deduct from input tax. Accounting practice mode is exactly the same with previous VAT payment. For example railway transport enterprise and postal enterprises. China published by the state for postal and transportation enterprises respectively value-added tax levy management interim measures "(The state administration of taxation announced in 2014, No. 5, 6) regulation. The sum of total sales agencies and their branches need to "reservation money" or "railway construction fund", regulations also announced that pre payment rate by the month and VAT may not offset the input tax. Parent agencies calculating current period tax payable, they can also be according to provisions of the state administration of taxation announced the 2014 \# 7 regulation. Specifically, it regulates Voucher deduction branch has prepaid the input tax and VAT.

Due to calculation of postal enterprise and railway transport does not belong to difference between tax law application scope, so tax regulations and accounting in state institution are the same as the goods and taxable services value-added tax accounting, while its subsidiaries or affiliated companies pre payment of the tax accounting is more simple, calculations and pre payment of value-added tax in each period only need to remark debt of "tax payable_-VAT payable", credit "bank deposits" and other subjects.

\subsection{The General Taxpayer Pilot Enterprises Accounting Calculation and Accounts Processing Specification}

With VAT policy and VAT Policy interim regulations are spread, interim tax policies of pilot enterprises gradually are abolished, accounting system and accounting treatment gradually become routine. But in practice, diversified business structure and service integration are common. For example, transportation companies involved repairs and replacement services, tourism services related sales. all of these suggest diversified characte- 
ristic. Another examples, company which owns truck for transporting, to bring cars and commercial vehicles as travel transport, some tourism companies serve tourists using their own cars, etc. to sum up, it exhibits integration features. If the enterprise engaged in sales goods, taxable services and change into category of taxable services, its taxable services shall implement the state administration of taxation announced tax [2013] No. 106 and other related files. At the same time the accounting treatment in accordance with the provisions of accounting standards; If they don't belong to side project, that is, authority of business scope for industry and commerce do not contain the taxable policies, to some extend, the main business actually changes. It means that this could be referred as "hybrid behavior", according to VAT regulations. The hybrid sales revenue of VAT taxpayers should be incorporated into goods sales, taxable services or sales from taxable services tax. Hybrid sales income should calculate including their turnover. When collaborative management behavior exists, there will be a lot of tax policy specification outside of the complicated situation. However, accountants should face seriously and calm down. For instant, when passenger cannot be sent to destination by transport company, they ask to tourism enterprises instead. Obviously, tourism companies have had hybrid sales behavior. Therefore, transport company can only issue printed invoices. According to current rules, enterprise did not obtain special invoices for value-added tax they can't offset the input tax.

For example: A transportation Co. LTD in Daqing City is a general VAT taxpayer. In October 2014, its total revenue was 4 million yuan, which get from domestic freight services revenue was 3.7 million yuan, pay a certain travel agency forwarding cost 444,000 yuan. At the same time it got services invoices from travel agency. It had to pay for transportation cost 1 million yuan, and obtain dairy company transport invoices. Its all sales revenue was 300,000 yuan. The shipment of the goods transportation income was 30,000 yuan. Assumptions in early leave its "tax credits" was 45,000 yuan, with the approval of the tax can deduction in October. How the transportation company deal accounting details

Analysis: as the passenger revenue belongs to transportation and VAT taxable services. It is suitable to $11 \%$ VAT rate, then its sales of goods applicable tax rate is $17 \%$. Therefore it engaged in different tax items shall be accounted for separately, otherwise rate is too high. In October, the VAT payable as follows:

1) The company transport business income is 3.7 million yuan, it should include output value added tax

Output tax $=(370+3) /(1+11 \%) \times 11 \%=36.96$ (ten thousand yuan), accountant processing is:

Debt: Bank deposit 3,700,000.

Credit: Main businesss revenue-Transportation income 3,330,400.

Tax payable-VAT payable (output tax) 369,600.

2) The company should from the travel agency to Open back service industry special invoice, but it cannot serve as the input tax deduction vouchers. On behalf of the freight paid 444,000 yuan, accounting should all included in the cost.

Debt: Main business cost, 440,000.

Credit: Bank deposit 440,000.

3) Transportation company get sales included tax revenue was 300,000 yuan, it should be tax by side business Output tax $=30 /(1+17 \%) \times 17 \%=4.36$ (ten thousand yuan), accounting for:

Debt: Bank deposit 300,000.

Credit: Other business income-Transport income 256,400.

Tax payable-VAT payable (Output tax) 43,600.

4) The company pay forwarding cost which could deduct input tax 1 million yuan (issuing special VAT invoice) Input tax $=100 /(1+11 \%) \times 11 \%=9.91$ (ten thousand yuan), accounting treatment:

Debt: Main business cost 900,900.

Taxes payable_-VAT payable (input VAT) 99,100.

Credit: Bank deposit 1,000,000.

5) According to the approval of the tax authorities, the company should carryover deductible remaining tax credit of 45,000 yuan at the beginning of the month.

Debt: Ttax payable_-VAT payable (input VAT) 45,000.

Credit: Tax payable-Added taxes 45,000.

6) In early September tax payable duration, transportation company should pay the value-added tax in August Value added tax payable $=36.96-4.4+4.36-(9.91+4.5)=22.51$ (ten thousand yuan).

Debt: tax payable_-VAT payable 225,100.

Credit: bank deposit 225,100. 


\subsection{VAT Accounting and Accounting Norms of Small Scale Taxpayers}

According to VAT policy documents, from August 1, 2013, small-scale taxpayers should do taxable services. Specifically, it should be according to the actual sales and 3\% tax rate to calculate VAT. When small-scale taxpayers do tax accounting, they typically set detail” taxes payable-VAT payable" [4]. At the end of accounting, it need to collect all current income which should be taxable and calculate the VAT payable, debit "main business income" and "other business income", credited "taxes payable_VAT payable "subjects. Companies should be accepted taxable services, in accordance with the provisions, shall not be deducted any input tax.

For example: A certified public accountants is a small-scale taxpayers, its total revenue was 2 million yuan in November 2014. Specifically, audit and verification cost was 1.85 million yuan, accounting consultancy revenue was 120,000 yuan, bookkeeping income was 30,000 yuan, pay a certain agency fees 500,000 yuan and obtain the special invoices of service industry. Given that its suitable levy rate was $3 \%$, accounting as follows:

1) VAT payable calculation of $B$ firm

VAT payable $=(185+12+3) /(1+3 \%) \times 3 \%=5.8252$ (ten thousand yuan).

2) Related VAT Accounting treatment of the company of B firm

a) The occurrence of business income

Debt: Bank deposit, etc. 2,000,000.

Credit: Main business income-Passenger revenue 2,000,000.

b) To pay agency fees, no deductible VAT, it should be paid included in the cost:

Debt: Operating expenses, 500,000.

Credit: Bank deposit 500,000.

c) Total revenue should include added tax at the end of final accounting:

Debt: Nain business income 58,252.

Credit: Tax payable_-VAT payable 58,252.

It should be emphasized that "the state administration of taxation on tax reform pilot VAT paid VAT general taxpayer qualification announcement of relevant matters of (the state administration of taxation announced No. 75 , 2013) regulation, the pilot taxpayers which combined sales goods, and provided repairs, replacement services and taxable services should calculated taxable goods labor output tax and taxable services respectively. It is suitable for VAT general taxpayer qualification standards. It suggests that it exists two kinds of special case of taxpayer identity, according to VAT reform situation. At this time, accountants should always keep calm down and stick to clearly separated accounting and tax. If the condition of financial strength permits, separated accounting could be regarded as the best choice, to some extend, it ensures that minimizes financial risk.

\subsection{VAT Remaining Tax Credit Accounting and Accounting Treatment Specification}

1) VAT remaining tax credit accounting

According to policy content validity, Fiscal [2013] No. 106 and its annex perhaps the most is the basic guiding policy for the service industry to expand their range of "Business tax change to vat". According to the provisions of, The general taxpayer who has both taxable services base on "Business tax change to vat" and has production and labor remaining tax credit before the date of pilot project, should calculate the deductible remaining and tax credit of goods and labors in the month of pilot project.

It assumes that the new reformed enterprise which applied VAT from January 1, as followed:

a) According to the general taxpayers application information and related items, it should calculate current output taxes of goods and labor services which account to the sum of the output tax relates goods and labor plus taxable services.

b)When calculate total amount of goods sales, labor services and taxable services, pilot companies should use output tax during the month minus input tax which matches all conditions.

c) Pilot companies' total tax payable during the month equals to tax payable multiplied by output tax of goods and services accounted to total output tax.

d) If pilot companies would like to compare amount of tax payable of goods and service to input tax on book value, the smaller one was permitted to deduct the remaining tax credits. If all current sales generated is less than the input tax and no VAT payable, the current tax cannot be offset the payment of goods and services tax credits, Hang on on account of the remaining tax credit should to be transferred to the later each tax period de- 
duction.

2) VAT remaining tax credit accounting treatment

The new Implement Business tax change to vat business, in the date of implementation of the policy, should not yet deductible goods input VAT of the original registration buying and selling of goods and taxable services with the VAT subsidiary accounts, turn out to "VAT remaining tax credit" in the details of subjects, accounting do:

Debit: Taxes payable-VAT remaining tax credit.

Credit: Taxes payable-VAT payable (input tax turns out).

The end of the period, calculated according to the provisions the amount of input tax of enterprises allowed deductions for the current period, Write off the original into the VAT of "VAT remaining tax credit" in the subsidiary ledger: accounting accounting treatment for:

Debit: Taxes payable-VAT payable (input tax).

Credit: Taxes payable-VAT remaining tax credit.

In this should be highlighted, each period accounting to write-downs of the VAT remaining tax credit, must correspond to the use of the original taxable goods and services produced by the output tax from continuing operations, but can not take up the income of the new VAT reform taxable services to create value-added tax be deducted. Otherwise, if the tax authorities examination revealed it will be adjusted, and give his appropriate penalties.

For example: A mould manufacturing company is a general taxpayer in development zone in A, in addition to do small loan financial business. From January 1, the state began to supervise VAT pilot. Given that, early month the debit "input tax" which is balance of 66,900 yuan; In January, sales income was 380,000 yuan, the output tax was 64,600 yuan, loan interest income (including taxes) was 110,800. It calculated output tax 10800 yuan; by purchasing goods to obtain special VAT invoices of input tax 19,800 yuan, The petty loan company to obtain an the purchase of equipment and printed vouchers "value added tax special invoice" records the amount of input tax is 6600 yuan. According to the above information, the company calculate save tax and tax payable as follow:

a) Goods output tax accounted for total financial service output tax:

Mould output tax is a proportion of output tax in January $=6.46 /(6.46+1.08) \times 100 \%=85.68 \%$.

All business tax payable in January $=(6.46+1.08)-(1.28+0.66)=5.6($ Ten thousand yuan $)$.

Goods and financial services tax payable in January $=5.6 \times 84.4 \%=4.8$ (Ten thousand yuan).

Compare with book value: $4.8<6.69$, that is, deducted tax credits was 48000 yuan in January

The value-added tax payable in August $=5.6-4.8=0.66$ (ten thousand yuan).

b) Accounting of leave tax credits

According to the above results, accounting is as follows:

On December 31, a):

Debt: Taxes payable-VAT remaining tax credit 66,900.

Credit: Taxes payable_-VAT payable (turn out input tax) 66,900.

When the company write balance sheet in January, it need to calculate "tax payable-added tax and save tax balance of 66,900 yuan, so called other current assets" project.

c) If pay VAT before February 15th, the company should be permitted to deduct 48000 yuan, accounting treatment is as follows:

Debt: Taxes payable-VAT payable (Input tax) 48,000.

Credit: Taxes payable—Value-added tax credits 48,000 .

Balance was18,900 yuan $(66,900$ - 48,000), is “Taxes payable-VAT remaining tax credit” final debit balance, should carried forward to the next period according to the provisions deduction.

\section{Conclusion}

In conclusion, VAT reform is accelerated in China from New Year's day in 2012 in Shanghai, to August 1, 2013 in all pilot companies. Then in January 2014, it continued to expand. It lasted over 2 years. Nowadays, new VAT pilots still added. Therefore, reformed policies must be different from the old ones. It could be referred as frequency changes of VAT policies. It will bring more new challenge [5]. Predictably, VAT policies would be completed in the near future. It means that current VAT policy needs to be guided by VAT law to incorporate. Meanwhile, accounting standards will be involved into VAT accounting regulations. However, it is important to 
check and manage tax policies and so on during transition period. To conclude, it is necessary to study related policies and regulations details. It is helpful to judge current situation changes and avoid potential taxable risk.

\section{Acknowledgements}

China "Business tax change to vat" is a complex and lengthy tax reform project, which provides a great space for academic research, but also to bring a lot of accounting problems. In this paper, the creation is complete, inseparable accounting colleagues to communicate inspired me a lot of consulting, business consulting sentiment is also inseparable from Daqing City Local Taxation Bureau Collection. Here, I solemnly authentic thank you! At the same time, would like to thank International Association for study of Information Technology and Science, provides me with the opportunity to publish this essay and recommendation; At the same time, get the Daqing city social science research project "Research on Daqing city to promote the reform of the taxation system" (number: 2015043) the fund support. And finally, thanks to my colleagues especially tax accounting teacher support and help, thank Hong Kong Baptist University Master of Accounting graduates Gao Bowen teacher giving translation papers help!

\section{References}

[1] Tang, Z. (2014) To Replace Business Tax with Value-Added Tax (VAT) of Enterprise Accounting and Tax Effect of Processing. New Wisdom (Financial Version), 77-78.

[2] Wang, S.F. and Liu, C. (2014) Effect of Policy to Replace Business Tax with Value-Added Tax Pilot Is Suggestions to Perfect. Accounting Study, 66-69.

[3] He, Y. (2014) Modern Service Industry. “Camp Changed by” Research Problems. Ph.D. Thesis, Yunnan University of Finance and Economics, Kunming.

[4] Xia, Y.H. (2013) Study on Related Issues of Business Tax Reform VAT. Chinese Collective Economy, 51-52.

[5] Peng, X.Y. and Liang, W.T. (2013) “Camp Changed by” Pilot Enterprises Accounting Treatment Operations. Accounting Monthly, 15, 55-56. 